\title{
Energy balance of irrigated maize silage
}

\author{
Tomás de Aquino Ferreira ${ }^{1}$ Sílvia Costa Ferreira ${ }^{*}$ Jackson Antônio Barbosa ${ }^{1}$ \\ Carlos Eduardo Silva Volpato ${ }^{1}$ Rute Costa Ferreira ${ }^{2}$ Marielle Jordane da Silva ${ }^{1}$ Leonardo Maia Barbosa ${ }^{1}$
}

'Departamento de Engenharia, Universidade Federal de Lavras (UFLA), Câmpus Universitário, Caixa Postal 3037, 37200-000, Lavras, MG, Brasil. E-mail: silvia.ferreira@deg.ufla.br. *Corresponding author.

${ }^{2}$ Instituto Nacional de Pesquisas Espaciais (INPE), Centro de Previsão de Tempo e Estudos Climáticos (CPTEC), Cachoeira Paulista, SP, Brasil.

ABSTRACT: The aim of the present study is to evaluate the energy balance and energy efficiency of the silage maize crop in the Center for Research, Development and Technology Transfer of the Universidade Federal de Lavras (CDTT-UFLA). The crop was irrigated by center pivot and the stages of maize cultivation and energy inputs were monitored for the $1^{\text {st }}$ and $2^{\text {nd }}$ crops of the 2014/2015 harvest. Results from the

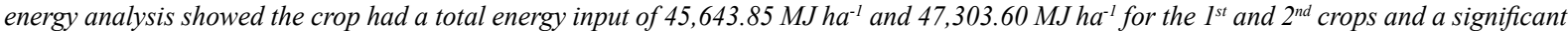
predominance of direct energy type (about $92 \%$ of the matrix). Regarding direct energy inputs, the diesel oil was the most representative, contributing with approximately $38 \%$ of the total energy demand. Conversely, the irrigation system contribute with $3.92 \%$ e $5.97 \%$ in the $1^{s t}$ and $2^{\text {nd }}$ crops, representing the largest indirect energy input. Nevertheless, irrigation and crop management allowed the system achieving high levels of productivity, resulting in an energy efficiency of 25.1 and 28.1 for the first and second crops respectively. Key words: energy efficiency, energy in agriculture, center pivot, sustainability.

Balanço energético da cultura do milho para silagem com irrigação

RESUMO: Este trabalho tem como objetivo avaliar o balanço energético e a eficiência energética da cultura milho para silagem implantada no Centro de Desenvolvimento e Transferência de Tecnologia da Universidade Federal de Lavras (CDTT-UFLA). A cultura foi irrigada por pivô central sendo que as etapas de cultivo do milho e entradas de energia foram acompanhadas para $1^{a}$ e $2^{a}$ safras do ano agrícola de 2014/2015. Os resultados da análise energética mostraram que a cultura teve uma entrada total de energia de 45.643,85MJ ha ${ }^{-1}$ e 47.303,60MJ ha $a^{-1}$ para a $1^{a}$ e $2^{a}$ safra, com uma predominância significativa de energia do tipo direta (cerca de $92 \%$ da matriz). O óleo diesel foi a fonte de energia direta que mais impactou na matriz, com uma participação de aproximadamente 38\%. Já a irrigação teve uma participação de 3,92\% e 5,97\% na $1^{a}$ e $2^{a}$ safra respectivamente, representando a maior fonte de energia indireta. Apesar disso, a irrigação e o manejo da cultura permitiram que o sistema alcançasse altos niveis de produtividade, resultando em uma eficiência energética de 25, 1 e 28,1 para a $1^{a}$ e $2^{a}$ safra. Palavras-chave: eficiência energética, energia na agricultura, pivô central, sustentabilidade.

\section{INTRODUCTION}

Since 1950s, Brazil has been undergoing a continued modernization process in agriculture, resulting in a significant increase in the use of agricultural machinery, fertilizers and pesticides. Inclusion of these technologies in agricultural systems has enabled producers to achieve greater profitability and significantly expanded the productive scale (TEIXEIRA, 2005). Conversely, it has intensified the use of different energy inputs, especially non-renewable ones. This growing demand, not only in the agricultural sector, makes increasingly evident the risks for a future energy crisis (HOUSHYAR et al.,2012).
For this reason, several research have been developed for studying the energy consumption of different crops, aiming to reduce losses and propose solutions that will become agricultural systems more sustainable. These studies make use of an important tool capable of evaluating the crop sustainability, called energy balance (CAMPOS \& CAMPOS, 2004).

Energy balance is the net difference between the energy demand and production. Conversely, energy efficiency is used to quantify the crop capacity of energy conversion, regardless of the net amount of energy consumed. This concept is used to compare different crop managements and evaluate which one is more efficient (ANGONESE et al. 2006; MELO et al., 2007; MARTINS et al., 2015). Total amount of 
demanded energy can be obtained from a survey of the quantity and types of inputs used in the crop and their respective energy coefficients (SÁ et al., 2013).

According to ZANINI et al. (2003) the energy inputs can be classified in two major groups: direct or indirect. The energy derived from fossil fuels, electricity, human or animal labor and seeds are classified as direct energy. Conversely, the indirect energy is related to the manufacture of machinery, buildings and installations, irrigation systems and others correlated inputs. From then on, several authors have been using the same classification in their energy analysis (ANGONESE et al., 2006; BIAGGIONI; BOVOLENTA, 2010; CUNHA et al., 2015; MARTINS et al., 2015; FERRO et al., 2017).

There is a great interest in the energy analysis of the maize crop, both for grain and silage. Recent researches evaluates the capability of energy conversion of maize crop, impact of an energy input and crop management in the energy balance (RIQUETTI; BENEZ; SILVA, 2012; HOUSHYAR et al., 2012; MARTINS et al., 2015; CUNHA et al., 2015).

The maize crop stands out among the national agriculture scenario and it is an important input of income in rural properties. In addition, the maize silage composes the major part of the rations, so it is essential for poultry breeders, swine, cattle and others (CRUZ et al., 2011; FERRO et al., 2017). In Brazil, irrigation systems are still not predominant in most maize crops, but its use allows the development of the $2^{\text {nd }}$ harvest (non-traditional times) and increases the productivity (CRUZ et al., 2011). Despite the irrigation adds inputs to the crop, which increases the total energy demand, several authors demonstrated that these systems can improve the energy efficiency (JORDAN et al., 2012).

Within this context, the present study evaluates the energy balance of a maize silage irrigated by a center pivot. The aim was to define the energy balance and efficiency, and also identify which inputs are more relevant to the matrix. Lastly, some possible wasting points in the crop can be identified and more sustainable options proposed.

\section{MATERIALS AND METHODS}

The present study was performed in the Center for Research, Development and Technology Transfer (CDTT-UFLA), located in the municipality of Ijaci, MG, Brazil, at coordinates $21^{\circ} 09^{\prime} 41^{\prime \prime} \mathrm{S}$ and $44^{\circ} 54^{\prime} 58^{\prime}$ ' W, $918 \mathrm{~m}$ altitude. The experimental area used 11 ha from the total 119.80ha of the CDDTUFLA. The soil was classified as red-yellow latosol (RYL) of clayey texture and the climate of the region is considered as humid temperate with dry winter and hot summer (Cwa) according to the Köppen classification (MARTINS et al.,2015).

\section{Design and implantation of maize silage}

Growing stages and maize silage design evaluated in the present study are consisted of preharvest crop desiccation, subsoiling, sowing and fertilization, irrigation, herbicide application after sowing, topdressing, harvesting, silo transport and silage compaction.

For pre-harvest crop desiccation, the herbicide Roundup Original (36\% glyphosate) was applied, with a dosage of $3.5 \mathrm{~L} \mathrm{ha}^{-1}$ and a volume of $300 \mathrm{~L}$ $\mathrm{ha}^{-1}$. The application was made with the IMEP IM-12 spot sprayer, coupled to the Valtra tractor model A750 $(75 \mathrm{cv})$. Subsoiling was performed using the Stara subsoiler, model ASA Laser KS, regulated for depth of approximately $25 \mathrm{~cm}$, coupled to the Massey Ferguson tractor, model MF283 (86hp).

In the sowing, the Biomatrix BM-840 PRO hybrid maize seed was used. The hybrid is transgenic and resistant to the main types of caterpillars and diseases. It has early cycle and double ability (silage and grain). A refuge area was seeded with non-transgenic seed, in order to make the pest control more efficient. A total of $60 \mathrm{~kg}$ of seeds per ha was used, resulting in a population of 75,000 plants per ha. In parallel, the NPK 8-28-16 chemical fertilizer was applied, with a dosage of $450 \mathrm{~kg} \mathrm{ha}^{-1}$. Chemical fertilizer dosages were based on the soil analysis performed by the certificate laboratory of Department of Soil Science, UFLA. The analysis was carried out in accordance with Interlaboratorial Program of Quality Control of Soil Analysis (PROFERT, 2005). For fertilizer application, a Jumil JM2680 pneumatic broadcast seeder was used, with six sowing units regulated for $60 \mathrm{~cm}$ spacing, coupled to the Massey Ferguson MF283 tractor. In the herbicide application, $2.5 \mathrm{~L} \mathrm{ha}^{-1}$ of Siptran $500 \mathrm{SC}$ (50\% atrazine) and $0.24 \mathrm{~L}$ $\mathrm{ha}^{-1}$ of Soberan (42\% tembotrione after sowing) with syrup volume of $200 \mathrm{~L} \mathrm{ha}^{-1}$. The IMEP IM-12 sprayer and the Valtra A750 tractor were used.

Topdressing was performed with NPK 300-20 fertilizer, with a dosage of $450 \mathrm{~kg} \mathrm{ha}^{-1}$. It was used the Baldan coverage fertilizer, model ACD-N, coupled to the Valtra A750 tractor.

The irrigation was performed by a center pivot manufactured by Círculo Verde, model CV.600.4. The pivot has four mobile towers and 68 sprinklers. It is capable of irrigating 10.4 ha of the 11 ha culture total. Pipelines are made of cast iron with $665 \mathrm{~m}$ length and flow of $83.7 \mathrm{~m}^{3} \mathrm{~h}^{-1}$, allowing a $4 \mathrm{~mm} /$ day gross depth. Pumping unit is composed of a 6-stage 
KSB-WKL 80/6pump (52.5hp), a 220mm rotor diameter, a nominal rotation of $1750 \mathrm{rpm}$ and a yield of approximately $69 \%$. Induction motor is a WEG W22 model $(54 \mathrm{cv})$. The pivot irrigation shift was 12 hours a day. After planting, irrigation was performed every two days until the beginning of the rainy season. The pivot worked approximately 30 days (360h) and for 45 days (540h) for the first and the second harvest respectively.

Regarding the harvest, it was used: a fodder manufactured by Nogueira, model Pecus 9004 coupled to the Massey Ferguson MF283 tractor; a Ford truck, model Cargo 2428E (275cv); a fodder manufactured by JF, model JF92 Z10 coupled to the New Holland tractor, model TL 85E and a Volvo truck, model VM270 (270cv) for transport. Inasmuch the harvest was performed, trucks transported the silage for storage in the silos and silage compaction. The compaction was performed by the Massey Fergunson MF283 tractor in the first harvest, and by the Valtra A750 tractor in the second one.

After finishing the silage process, 12 samples were taken with approximately $300 \mathrm{~g}$ each. These samples were analyzed in order to obtain the gross heating value $(\mathrm{GHV})$ of silage $\left(\mathrm{EC}_{\text {silage }}\right)$, using the IKA calorimeter model $\mathrm{C} 2000$, following the ABNT NBR 8633 standard (ABNT, 1984).

\section{Energy analysis}

In the present study, the direct energy, related to the labor force $\left(\mathrm{E}_{\mathrm{lf}}\right)$, seeds $\left(\mathrm{E}_{\text {seed }}\right)$, diesel oil
$\left(\mathrm{E}_{\mathrm{do}}\right)$, lubricants $\left(\mathrm{E}_{\text {lub }}\right)$ and greases $\left(\mathrm{E}_{\mathrm{grs}}\right)$, was obtained through the definition of energy coefficients and the amount of material used per ha. Energy coefficients were determined according to the literature and are presented in table 1. Conversely, the direct energy, related to the use of chemical fertilizers based on NPK $\left({ }_{\text {fer }}\right)$, liquid agricultural pesticides $\left(\mathrm{E}_{\mathrm{pc}}\right)$ and electricity $\left(\mathrm{E}_{\mathrm{e}}\right)$, was calculated based on Eqs. 1 to 3 (ROMANELLI \& MILAN, 2005).

$E_{\text {fer }}=\left(a \cdot E C_{N}+b \cdot E C_{p}+c \cdot E C_{K}\right) \cdot Q_{\text {fer }}$ where, $\mathrm{EC}_{\mathrm{N}}, \mathrm{EC}_{\mathrm{P}}$ and $\mathrm{EC}_{\mathrm{k}}$ are the energy coefficients of each active element $\left(\mathrm{N}, \mathrm{P}_{2} \mathrm{O}_{5}\right.$ and $\left.\mathrm{K}_{2} \mathrm{O}\right)$ in $\mathrm{MJ} \mathrm{kg}^{-1}$, respectively; $\mathrm{a}, \mathrm{b}$ and $\mathrm{c}$ are the quantities of each product in $\mathrm{kg}$ per $100 \mathrm{~kg}$ of fertilizer; $\mathrm{Q}_{\mathrm{fer}}$ is the quantity of fertilizer used in $\mathrm{kg} \mathrm{ha}^{-1}$.

$E_{p c}=\left(C_{a i} \cdot Q_{p c}\right) \cdot E C_{p c}$ where, $\mathrm{EC}_{\mathrm{pc}}$ is the energy coefficient of the pesticide (MJ L L); ${ }^{-1} \mathrm{C}_{\mathrm{ai}}$ is the concentration of the active ingredient (decimal) and $\mathrm{Q}_{\mathrm{pc}}$ is the amount of pesticide used per hectare $\left(\mathrm{L} \mathrm{ha}^{-1}\right)$.

$E_{e l}=\left(\frac{P \cdot T_{D U} \cdot N}{A}\right) \cdot E C_{e l}$

where, $\mathrm{EC}_{\mathrm{el}}$ is the energy coefficient of electricity; $\mathrm{P}$ is the motor nominal power of the pumping system $(\mathrm{kW})$; $\mathrm{T}_{\mathrm{DU}}$ is the time of daily use (h); $\mathrm{N}$ is the number of irrigation days, and $\mathrm{A}$ is the total crop area (ha).

Calculation of indirect energy of agricultural machinery and implements $\left(\mathrm{E}_{\text {macimp }}\right)$ was based on the concept of energy depreciation, as described in the Eq. 4 (MARTINS et al., 2015).

Table 1 - Direct and indirect energy inputs related to irrigated maize silage cultivation and its respective energy coefficients.

\begin{tabular}{|c|c|c|c|}
\hline Energy inputs & Unit & Energy coefficient & Reference \\
\hline \multicolumn{4}{|c|}{-------------------------------------------------------------------------Direct energy----------------------------------------------------------------------- } \\
\hline Labor force & $\mathrm{MJ} \mathrm{h}^{-1}$ & 2.20 & ROMANELLI et al. (2012) \\
\hline Seeds & $\mathrm{MJ} \mathrm{kg}^{-1}$ & 18.71 & (MARTINS et al., 2015) \\
\hline Diesel oil & $\mathrm{MJ} \mathrm{L}^{-1}$ & 35.50 & $($ EPE, 2016) \\
\hline Lubricants & $\mathrm{MJ} \mathrm{L}^{-1}$ & 36.43 & (EPE, 2016) \\
\hline Greases & $\mathrm{MJ} \mathrm{kg}^{-1}$ & 38.77 & (EPE, 2016) \\
\hline \multicolumn{4}{|l|}{ Fertilizers } \\
\hline $\mathrm{N}$ & $\mathrm{MJ} \mathrm{kg}^{-1}$ & 74.00 & ROMANELLI et al. (2012) \\
\hline $\mathrm{P}_{2} \mathrm{O}_{5}$ & $\mathrm{MJ} \mathrm{kg}^{-1}$ & 12.56 & ROMANELLI et al. (2012) \\
\hline $\mathrm{K}_{2} \mathrm{O}$ & $\mathrm{MJ} \mathrm{kg}^{-1}$ & 6.70 & ROMANELLI et al. (2012) \\
\hline \multicolumn{4}{|l|}{ Pesticides } \\
\hline Glyphosate (36\%) & $\mathrm{MJ} \mathrm{L}^{-1}$ & 454.20 & (ROMANELLI \& MILAN, 2005) \\
\hline Atrazine $(50 \%)$ & $\mathrm{MJ} \mathrm{L}^{-1}$ & 188.38 & (ROMANELLI \& MILAN, 2005) \\
\hline Tembotrione $(42 \%)$ & $\mathrm{MJ} \mathrm{L}^{-1}$ & 254.57 & (ROMANELLI \& MILAN, 2005) \\
\hline Electricity & $\mathrm{MJ} \mathrm{kWh}^{-1}$ & 3.60 & $(\mathrm{EPE}, 2016)$ \\
\hline \multicolumn{4}{|c|}{------------------------------------------------------------------------Indirect energy--------------------------------------------------------------------------' } \\
\hline Machinery & $\mathrm{MJ} \mathrm{kg}^{-1}$ & 69.83 & (MARTINS et al.,2015) \\
\hline Implements & $\mathrm{MJ} \mathrm{kg}^{-1}$ & 57.20 & (MARTINS et al.,2015) \\
\hline
\end{tabular}

Ciência Rural, v.48, n.5, 2018. 


$$
E_{m a c / i m p}=\left(\frac{W \cdot T_{U}}{V_{U} \cdot A}\right) \cdot E C_{m a c / i m p}
$$

where, $\mathrm{W}$ is the equipment weight $(\mathrm{kg})$; $\mathrm{EC}_{\text {mac }}$ is the energy coefficient used for machinery $\left(\mathrm{MJ} \mathrm{kg}^{-1}\right) ; \mathrm{EC}_{\text {imp }}$ is the energy coefficient used for agricultural implements $\left(\mathrm{MJ} \mathrm{kg}^{-1}\right) ; \mathrm{T}_{\mathrm{U}}$ is the time of use (h); $\mathrm{V}_{\mathrm{U}}$ is the useful life of machinery (h), and $\mathrm{A}$ is the total crop area.

The indirect energy related to the manufacturing of irrigation equipment $\left(\mathrm{E}_{\mathrm{irr}}\right)$ was obtained by the methodology proposed by DIOTTO et al. (2014). Indirect energy of the irrigation equipment was split into: energy of the pumping system ( $\left.\mathrm{E}_{\text {pump }}\right)$, of the pipeline $\left(\mathrm{E}_{\mathrm{p}}\right)$, and of the center pivot irrigation system $\left(\mathrm{E}_{\text {pivot }}\right)$, which was obtained according to the Eq. 5 to 7.

$$
E_{\text {pump }}=\left(\frac{7.62 \cdot P}{A_{i r r}}\right) \cdot F_{a j}
$$

where, $\mathrm{P}$ is the pump power $(\mathrm{kW}) ; \mathrm{F}_{\mathrm{aj}}$ is the adjustment factor to fit the run time of the system when it is less than one year (years), and $A_{i r r}$ is the irrigated area in hectares (ha).

$$
E_{p l}=\left(\frac{\left[0.7242 \cdot Q_{p l}+54.642\right] \cdot L_{a d}}{A_{i r r}}\right) \cdot F_{a j}
$$

where, $\mathrm{Q}_{\mathrm{pl}}$ is the pipeline flow $\left(\mathrm{m}^{3} \mathrm{~h}^{-1}\right)$ and $\mathrm{L}_{\mathrm{ad}}$ is the pipeline length $(\mathrm{m})$.

$$
E_{\text {pivot }}=10318 \cdot A_{\text {irr }}{ }^{-0.53} \cdot F_{a j}
$$

The input energy $\left(\mathrm{E}_{\text {input }}\right)$ was obtained by summing the energy demand of each input presented previously. The output energy $\left(\mathrm{E}_{\text {output }}\right)$ was obtained by multiplying the silage heating value $\left(E C_{\text {silage }}\right)$ by the crop productivity. Finally, the energy analysis of maize crop, made use of two efficiency indices, as described by CUNHA et al. (2015) and calculated according to Eq. 8 and 9.

Energy balance $=E_{\text {output }}-E_{\text {input }}$

Energy $\cdot$ efficiency $=\frac{E_{\text {output }}}{E_{\text {input }}}$

\section{RESULTS AND DISCUSSION}

The information regarding the first and second harvests of 2014/2015 are presented in table 2, which includes energy matrix, output energy, share (\%) of each input in the total energy consumption, accounting and energy efficiency.

The total energy consumption values were approximately $45,643.85 \mathrm{MJ} \mathrm{ha}^{-1}$ for the first harvest and $47,303.60 \mathrm{MJ} \mathrm{ha}^{-1}$ for the second. These values were significantly higher than found by MARTINS et al. (2015) and CUNHA et al. (2015), which were 14,471 and $16,452 \mathrm{MJ} \mathrm{ha}^{-1}$, respectively. These authors performed similar experiments in the same region, but did not consider the energy spent in the process of silage compaction and transport, neither the energy spent irrigation systems.

It was possible to observe a strong predominance of direct energy consumption $(42,357.67$ and $\left.43,118.56 \mathrm{MJ} \mathrm{ha}^{-1}\right)$ in comparison to the indirect one $\left(3,286.18\right.$ and 4,185.04MJ ha $\left.{ }^{-1}\right)$. Most of the authors that used a similar energy classification also reported a greater influence of direct energy in their energy matrix (ANGONESE et al., 2006; BIAGGIONI; BOVOLENTA, 2010; CUNHA et al., 2015; MARTINS et al., 2015).

Regarding energy inputs, the diesel oil showed the highest energy demand, with a share above $37 \%$ in both harvests. The second largest demand was from fertilizer, which showed the share of $33.57 \%$ and $28.79 \%$ in the matrix for the first and second harvests respectively. This was mainly due to the high-energy demand for Nitrogen (NPK) production. According to the soil fertility analysis, the recommended dosage of NPK was smaller in the second harvest, which reduced the demand of fertilizers. Several authors that performed the energy balance of maize crop for grain and silage presented the fertilizers as the main input of energy consumption (CUNHA et al.,2015; MARTINS et al.,2015; VEIGA et al.,2015; LIN et al.,2016; FERRO et al.,2017).

Electricity used by the irrigation system was the third largest demand of the matrix, with a share of $10.84 \%$ and $15.70 \%$, for the first and second harvests, respectively. The observed contrast of energy consumption between the two harvests can be justified by the higher irrigation period adopted in the second harvest, due to the climatic conditions of this time of year. This difference also influences on the energy depreciation of the irrigation equipment, which consequently results in a larger indirect energy demand for the second harvest. Electricity is indicated by some authors as the most significant energy input within the irrigated systems (JORDAN et al.,2012; DIOTTO et al.,2014; CARMO et al.,2016).

Other inputs of direct energy, such as labor force, seeds, lubricants, grease and pesticides have less impact on the energy matrix, with share lower than $2.5 \%$. The low participation of inputs with seeds and labor force showed a tendency observed in several studies (ROMANELLI et al., 2012; JORDAN et al., 2012; MARTINS et al., 2015; CUNHA et al., 2015; CARMO et al., 2016).

The indirect energy inputs represented a small percentage of the energy matrix, with participation of $7.20 \%$ and $8.85 \%$, in the first and second harvests, respectively. The greatest indirect energy consumer was the irrigation equipment $(3.92 \%$ in the first and $5.67 \%$ in the second harvest), followed 
Table 2 - Energy matrix of the maize silage cultivated in the Center for Research, Development and Technology Transfer of the Federal University of Lavras (CDTT-UFLA), Ijaci, MG, $1^{\text {st }}$ and $2^{\text {nd }}$ crops of 2014/2015.

\begin{tabular}{|c|c|c|c|c|}
\hline \multirow{2}{*}{$\begin{array}{l}\text { Input } \\
\text { Direct energy }\end{array}$} & \multicolumn{2}{|c|}{--------------------1 ${ }^{\text {st }}$ harvest------------------ } & \multicolumn{2}{|c|}{------------------2 ${ }^{\text {nd }}$ harvest--------------- } \\
\hline & $\mathrm{MJ} \mathrm{ha}^{-1}$ & Participation & $\mathrm{MJ} \mathrm{ha}^{-1}$ & Participation \\
\hline Labor force & 809.60 & $1.77 \%$ & 809.60 & $1.71 \%$ \\
\hline Seeds & $1,122.60$ & $2.46 \%$ & $1,122.60$ & $2.37 \%$ \\
\hline Diesel oil & $17,660.70$ & $38.69 \%$ & $17,716.28$ & $37.45 \%$ \\
\hline Lubricants & $1,002.92$ & $2.20 \%$ & $1,010.38$ & $2.14 \%$ \\
\hline Greases & 656.20 & $1.44 \%$ & 581.69 & $1.23 \%$ \\
\hline Fertilizers & $15,322.50$ & $33.57 \%$ & $13,620.00$ & $28.79 \%$ \\
\hline $8-28-16$ & $4,729.50$ & $10.36 \%$ & $4,204.00$ & $8.89 \%$ \\
\hline $30-0-20$ & $10,593.00$ & $23.21 \%$ & $9,416.00$ & $19.91 \%$ \\
\hline Pesticides & 833.43 & $1.83 \%$ & 833.43 & $1.76 \%$ \\
\hline Glyphosate (36\%) & 572.29 & $1.25 \%$ & 572.29 & $1.21 \%$ \\
\hline Atrazine $(50 \%)$ & 235.48 & $0.52 \%$ & 235.48 & $0.50 \%$ \\
\hline Tembotrione $(42 \%)$ & 25.66 & $0.06 \%$ & 25.66 & $0.05 \%$ \\
\hline Electricity & $4,949.72$ & $10.84 \%$ & $7,424.58$ & $15.70 \%$ \\
\hline Total direct energy & $42,357.67$ & $92.80 \%$ & $43,118.56$ & $91.15 \%$ \\
\hline Indirect energy & $\mathrm{MJ} \mathrm{ha}^{-1}$ & Participation & $\mathrm{MJ} \mathrm{ha}^{-1}$ & Participation \\
\hline Machinery & 963.31 & $2.11 \%$ & 967.75 & $2.05 \%$ \\
\hline Implements & 534.02 & $1.17 \%$ & 534.02 & $1.13 \%$ \\
\hline Irrigation & $1,788.85$ & $3.92 \%$ & $2,683.27$ & $5.67 \%$ \\
\hline Pumping & 5.24 & $0.01 \%$ & 7.86 & $0.02 \%$ \\
\hline Pipeline & $1,246.78$ & $2.73 \%$ & $1,870.16$ & $3.96 \%$ \\
\hline Center pivot & 536.83 & $1.18 \%$ & 805.25 & $1.70 \%$ \\
\hline Total indirect energy & $3,286.18$ & $7.20 \%$ & $4,185.04$ & $8.85 \%$ \\
\hline Total power input & 45,644 & $100.00 \%$ & 47,304 & $100 \%$ \\
\hline Power output & $1,143,864$ & - & $1,330,914$ & - \\
\hline Energy balance & $1,098,220$ & - & $1,283,610$ & - \\
\hline Energy efficiency & 25.1 & - & 28.1 & - \\
\hline
\end{tabular}

by the machinery $(2.11 \%$ in the first and $2.05 \%$ in the second crop). Despite the high degree of crop mechanization, the machinery has a small share in the matrix due to the methodology adopted for energy depreciation. Although, share of irrigation equipment in the energy matrix is small $(<6 \%)$, these equipment represented the input with the highest indirect energy consumption and the fourth largest energy consumption of the matrix. The energy expenditure of $1,788.85$ and $2,683.27 \mathrm{MJ} \mathrm{ha}^{-1}$ referring the first and second harvests, respectively, was higher than some direct energy inputs, such labor force, seeds, lubricants, grease and pesticides.

Output energy was recorded through the relationship between the crop productivity and the energy coefficient of produced silage. The energy coefficient of the maize silage was obtained based on data analysis of the gross heating value (GHV) performed in samples taken from the silo. Results were 19.06 and $18.48 \mathrm{MJ} \mathrm{kg}^{-1}$ for the first and second harvests, respectively. The crop reached a productivity of $60 \mathrm{tha}^{-1}$ for the first harvest and $72 \mathrm{t}$ $\mathrm{ha}^{-1}$ for the second. Second harvest productivity was $20 \%$ higher because its growing was subjected to a larger photoperiod of year (February to May), besides being irrigated. Due to the high levels of productivity, the values of output energy $(1,143.8$ and $1,330.9 \mathrm{GJ}$ $\left.\mathrm{ha}^{-1}\right)$ were much higher than reported by other authors (ZANINI et al., 2003; KOMLEH et al., 2011; MARTINS et al., 2015; LIN et al., 2016).

The authors MARTINS et al. (2015) and LIN et al. (2016), which did not consider irrigated crops, obtained an output energy of 140.1 and $345 \mathrm{GJ}$ $\mathrm{ha}^{-1}$, for the first and second harvests respectively. Both authors adopted values for energy coefficients similar to the ones presented in this study (17.32 and $19 \mathrm{MJ} \mathrm{kg}^{-1}$ ). Nevertheless, the productivity result was around 8 and $18.8 \mathrm{tha}^{-1}$, respectively. 
Conversely, ZANINI et al. (2003) and KOMLEH et al. (2011), which considered irrigated crops, obtained energy outputs of 206.7 and 148.4GJ $\mathrm{ha}^{-1}$, with yields of 10.6 and $18.5 \mathrm{tha}^{-1}$, respectively. These values are below those shown in the present study. It is known that the high achieved productivity is not only related to irrigation, but also it is necessary to consider other factors, such as nitrogen fertilization, maize hybrid, management, spacing of planting, among others. The influence of these factors in maize productivity have been evaluated and tested by other authors (TURGUT et al., 2005; PAVINATO et al., 2008; ISLAM et al. 2012; JORDAN et al., 2012).

The analyzed crop showed a very positive energy balance, with a net energy of 1,098.2 and $1,283.6 \mathrm{GJ} \mathrm{ha}^{-1}$, resulting in an energy efficiency of 25.1 and 28.1 for the first and second harvests, respectively. Results are considered as high in comparison to others know in the literature. For instance, the crop analyzed by MARTINS et al. (2015) showed an energy input about three times lower than those from the present study did. However, productivity was significantly lower, resulting in an energy efficiency of 9.69 (spacing of $0.6 \mathrm{~m}$ ). LIN et al. (2016), in turn, showed an energy efficiency of 20.4 and 33.5 for maize silage in conventional farms and for agroforestry systems, respectively.

Despite the positive balance, the crop can achieve better levels and reduce the total demand through the investment in more sustainable managements which optimizes the energy demand from chemical fertilizers, electricity and oil diesel. Some sustainable actions include the use of organic fertilizers instead of chemical ones (FERRO et al., 2017); the implantation of crop rotation in order to reduce the use of NPK fertilizers (CAMPOS \& CAMPOS, 2004); the use of automated irrigation systems with variable speed drives, aiming to reduce water and electricity consumption (MORAES et al., 2011), among others. Furthermore new approaches for improving the oil diesel consumption, especially in the harvesting and transport to the silo, are alternative sustainable actions which can refine the results.

\section{CONCLUSION}

The maize crop evaluated on this study showed positive results of energy balance despite high values of total energy demand. The direct energy inputs were predominant due to the significant participation of the diesel oil, chemical fertilizers and electricity used for irrigation.

Large values of energy input were compensated by an appropriate performance of the system conversion capability. These results led to a relatively high energy efficiency, better than other values reported in the literature.

Lastly, it was observed that the crop management contributed to improve the energy efficiency. Moreover, some improvements can lead the maize crop to be more sustainable, such as, the use of: organic fertilizers, automated irrigation systems and crop rotation.

\section{ACKNOWLEDGEMENTS}

The authors acknowledge the financial support of Universidade Federal de Lavras (UFLA), Fundação de Amparo à Pesquisa do Estado de Minas Gerais (FAPEMIG) and Conselho Nacional de Desenvolvimento Científico e Tecnológico (CNPq).

\section{DECLARATION OF CONFLICTING INTERESTS}

We have no conflict of interest to declare.

\section{REFERENCES}

ABNT. NBR 8633: Carvão vegetal: determinação do poder calorífico. Rio de Janeiro: Associação Brasileira de Normas Técnicas, 1984. 13 p.

ANGONESE,A. R. et al. Energy efficiency of swine production system with biodigestor waste treatment. Revista Brasileira de Engenharia Agrícola e Ambiental, v. 10, n. 3, p. 745-750, 2006. Available from: < http://dx.doi.org/10.1590/S1415-43662006000300030>. Accessed: Nov. 2017. doi:10.1590/S1415-43662006000300030.

BIAGGIONI, M. A. M. et al. Comparative energy analysis for soybean journey transport. Engenharia Agrícola. Associação Brasileira de Engenharia Agrícola, v. 30, n. 4, p. 587-599, 2010. Available from: $<$ http://dx.doi.org/10.1590/S0100-69162010000400003>. Accessed: Apr. 2017. doi: 10.1590/S0100-69162010000400003.

CAMPOS, A. T. et al. Agricultural energy balance: an important tool as indicative of sustainability of agricultural ecosystems. Ciência Rural, v. 34, n. 6, p. 1977-1985, Nov. 2004. Available from: <http:// dx.doi.org/10.1590/S0103-84782004000600050>. Accessed: Oct. 2017. doi: $10.1590 / \mathrm{S} 0103-84782004000600050$.

CARMO, H. F. do et al. Energy balance and carbon footprint in the conventional and integrated production systems of irrigated common bean. Pesquisa Agropecuária Brasileira, v. 51, n. 9, p. 1069-1077. 2016. Available from: <http://dx.doi.org/10.1590/ S0100-204X2016000900006>. Accessed: Nov. 2016. doi: 10.1590/ S0100-204X2016000900006.

CRUZ, J. C. et al. Milho: o produtor pergunta, a Embrapa responde. Embrapa Informação Tecnológica, 2011. v. 1. 2011. Available from: <http://www.infoteca.cnptia.embrapa.br/ infoteca/handle/ doc/921542>. Accessed: Nov. 2016.

CUNHA, J. P. B. et al. Energy demand of different soil managements in corn crop. Bioscience Journal, v.31, n.3, 2015. Available from: $<$ http://dx.doi.org/10.14393/BJ-v31n3a2015-22431>. Accessed: Dec. 2016. doi: 10.14393/BJ-v31n3a2015-22431.

DIOTTO, A. et al. Embodied energy associated with the materials used in irrigation systems: Drip and center pivot. Biosystems 
engineering, v. 121, p. 38-45, 2014. Available from: <http://dx.doi. org/10.1016/j.biosystemseng.2014.02.002>. Accessed: Jan. 2017. doi: 10.1016/j.biosystemseng.2014.02.002.

EPE. Balanço Energético Nacional. Ministério de Minas e Energia - Empresa de Pesquisas Energéticas. 2016. Online. Available from: $<$ https://ben.epe.gov.br/>. Accessed: Oct. 2016.

FERRO, N. D. et al. Crop yield and energy use in organic and conventional farming: A case study in north-east Italy. European Journal of Agronomy, v. 86, p. 37-47, 2017. Available from: <http:/ dx.doi.org/10.1016/j.eja.2017.03.002>. Accessed: Apr. 2017. doi: 10.1016/j.eja.2017.03.002.

HOUSHYAR, E. et al. Sustainable and efficient energy consumption of corn production in southwest Iran: Combination of multi-fuzzy and dea modeling. Energy, v.44, p.672-681, 2012. Available from: <http://dx.doi.org/10.1016/j.energy.2012.05.025>. Accessed: Apr. 2017. doi: 10.1016/j.energy.2012.05.025.

ISLAM, M. R. et al. Effects of irrigation and rates and timing of nitrogen fertilizer on dry matter yield, proportions of plant fractions of maize and nutritive value and in vitro gas production characteristics of whole crop maize silage. Animal Feed Science and Technology. v.172, p.125-135. 2012. Available from: $<$ http://dx.doi.org/10.1016/j. anifeedsci.2011.11.013>. Accessed: Apr. 2017. doi: 10.1016/j. anifeedsci.2011.11.013

JORDAN, R. A. et al. Energetic impact of drip irrigation on castor bean crop. Pesquisa Agropecuária Tropical, v. 42, n. 4, p. 375 382, 2012. Available from: <http://www.redalyc.org/articulo. oa? $\mathrm{id}=253025284005>$. Accessed: Oct. 2017.

KOMLEH, S. P. et al. Energy use and economic analysis of corn silage production under three cultivated area levels in Tehran province of Iran. Energy, v. 36, p. 3335-3341, 2011. Available from: $<$ http://dx.doi.org/10.1016/j.energy.2011.03.029>. Accessed: Oct. 2017. doi: 10.1016/j.energy.2011.03.029

LIN, H. C. et al. Effects of changing farm management and farm structure on energy balance and energy-use efficiency - a case study of organic and conventional farming systems in southern Germany. European Journal of Agronomy - Online, v. 82, p. 242-253, 2016 Available from: <http://dx.doi.org/10.1016/j.eja.2016.06.003>. Accessed: Apr. 2017. doi: 10.1016/j.eja.2016.06.003.

MARTINS, F. G. L. et al. Energetic analysis of corn production for silage grown in different spacing. Energia na Agricultura, v. 30, n. 4, 2015. Available from: <http://dx.doi.org/10.17224/ EnergAgric.2015v30n4p418-428>. Accessed: Oct. 2017. doi: 10.17224/EnergAgric.2015v30n4p418-428.
MELO, D. et al. Energetic balance of soybean and corn production systems in a farm of the west of Paraná, Brazil. Acta ScientiarumAgronomy, Maringá, v. 29, n. 2, p. 173-178, 2007. Available from: <http://dx.doi.org/10.4025/actasciagron.v29i2.233>. Accessed: Apr. 2017. doi: 10.4025/actasciagron.v29i2.233.

MORAES, M. J. de et al. Demand side management for water pumping for irrigated perimeter. Revista Brasileira de Engenharia Agrícola e Ambiental, v. 15, n. 9, p. 875-882, 2011. Available from: $<\mathrm{http} / / /$ dx.doi.org/10.1590/S1415-43662011000900001>. Accessed: Apr. 2017. doi: 10.1590/S1415-43662011000900001.

PAVINATO, P. S. et al. Nitrogen and potassium in irrigated corn technical and economic analysis of the fertilization. Ciência Rural, v. 38, n. 2. pp. 358-364. 2008. Available from: $<$ http://www. scielo.br/pdf/cr/v38n2/a10v38n2.pdf>. Accessed: Apr. 2017.

PROFERT. Manual do Laboratorista. Programa Interlaboratorial de Controle de Qualidade de Análise do Solo, ed. 1, p.1-33, 2005. Online. Available from: <http://www.profertmg. com.br/secao. htm? idSecao $=47>$. Accessed: Jan 2018.

RIQUETTI, N. B. et al. Energy demand in different soil tillage and corn hybrids. Revista Energia na Agricultura, v. 37, n. 2, 2012. Available from: <http://dx.doi.org/10.17224/ EnergAgric.2012v27n2p76-85>. Accessed: Nov. 2016. doi: 10.17224/EnergAgric.2012v27n2p76-85.

ROMANELLI, T. L. et al. Energy balance methodology and modeling of supplementary forage production for cattle in Brazil. Scientia Agricola, v. 62, n. 1, p. 1-7, 2005. Available from: <http:// dx.doi.org/10.1590/S0103-90162005000100001>. Accessed: Nov. 2016. doi: 10.1590/S0103-90162005000100001.

ROMANELLI, T. L. et al. Material embodiment and energy flows as efficiency indicators of soybean (Glycine max) production in Brazil. Engenharia Agrícola, Joboticabal, v. 32, p. 261-270, 2012. Available from: <http://dx.doi.org/10.1590/S0100-69162012000200006>. Accessed: Apr. 2017. doi: 10.1590/S0100-69162012000200006.

SÁ, J. M. et al. Energy balance for the production of grain, meat, and biofuel in specialized and mixed agrosystems. Pesq. agropec. bras., v. 48, n. 10, p. 1323-1331, 2013. Available from: <http:// dx.doi.org/10.1590/S0100-204X2013001000003>. Accessed: Apr. 2017. doi: 10.1590/S0100-204X2013001000003.

ZANINI, A. et al. Energy consumption analysis of corn silage production in non-tillage crop system Acta Scientiarum. Animal Sciences, v. 25, n. 2, 2003. Available from: <http://dx.doi. org/10.4025/actascianimsci.v25i2.1980>. Accessed: Apr. 2017. doi: 10.4025/actascianimsci.v25i2.1980. 